\title{
PEMETAAN SEBARAN TITIK PANAS DI KABUPATEN KUBU RAYA
}

\author{
Sujiman, Naomi Nessyana Debataraja, Yundari
}

\begin{abstract}
INTISARI
Titik panas (hotspot) merupakan indikator kebakaran hutan yang mendeteksi suatu lokasi yang memiliki suhu relatif lebih tinggi. Sebaran titik panas merupakan hasil pengamatan dari satelit-satelit yang mengudara di atas Bumi. Penelitian ini bertujuan untuk memetakan sebaran titik panas di Kabupaten Kubu Raya. Dalam penelitian ini digunakan variabel pengamatan diantaranya adalah latitude dan longitude yang berguna untuk melihat lokasi titik panas, serta confidence sebagai level titik panas. Kemudian dilakukan analisis variansi untuk mengetahui perbedaan rata-rata nilai jumlah titik panas setiap kecamatan. Kemudian dilakukan visualisasi menggunakan sistem informasi geografis untuk melihat peta sebaran titik panas pada tingkat kabupaten, kecamatan, desa dan penggunaan lahan di Kabupaten Kubu Raya.
\end{abstract}

Kata Kunci: Pemetaan, Latitude, Longitude, Confidence, Analisis Variansi.

\section{PENDAHULUAN}

Indonesia memiliki luas hutan yang menduduki urutan ketiga terluas di dunia, dengan hutan tropis dan hutan hujan di Kalimantan dan Papua [1]. Namun seiring berjalannya waktu, Indonesia mengkonversi lahan hutan tersebut mejadi lahan non hutan atau sering disebut dengan istilah deforasi. Deforasi merupakan fenomena normal dalam proses pembangunan setiap negara di dunia. Waktu terjadinya deforasi di setiap negara bergantung pada periode proses pembangunan. Pembangunan yang terus meningkat akan sangat berpengaruh signifikan pada luas kawasan hutan, sehingga perlu penanganan khusus untuk mengendalian kerusakan hutan yang terjadi yang diakibatkan oleh deforasi.

Pulau Kalimantan adalah salah satu paru-paru dunia dengan luas hutan sekitar 40,8 juta hektar [2]. Kebakaran hutan dan lahan di Indonesia umumnya disebabkan oleh manusia, baik disengaja maupun akibat kelalaian, seperti adanya konversi lahan, kegiatan penyiapan lahan, dan pembukaan lahan untuk pertanian maupun perkebunan dengan cara pembakaran. Sedangkan sisanya adalah karena alam, seperti petir dan larva gunung berapi [3].

Tujuan dari penelitian ini adalah menganalisis sebaran titik panas di Kabupaten Kubu Raya dan membandingkan rata-rata pada setiap kecamatan. Penelitian ini dapat membantu memberi gambaran daerah yang rawan terjadi kebakaran di Kabupaten Kubu Raya. Penelitian ini dibatasi pada data titik panas dengan mengklasifikasi menjadi tiga zona yaitu hijau yang diartikan sebagai pendugaan titik api, kuning diartikan kemungkinan titik api tergantung struktur tanah, dan merah diartikan sebagai rawan titik api, serta pemetaan yang dilakukan pada tingkat kabupaten, kecamatan, desa, dan penggunaan lahan.

Tahapan pemetaan sebaran titik panas di Kabupaten Kubu Raya yang pertama kali dilakukan adalah menginput data polygon Kalimantan Barat, Kabupaten Kubu Raya, kecamatan, desa, penggunaan lahan, titik koordinat $(x, y)$, dan confidence. Langkah berikutnya adalah mengelompokkan titik panas berdasarkan level confidence. Kemudian membuat peta sebaran titik panas pada tingkat kabupaten, kecamatan, desa dan penggunaan lahan. Setelah dilakukan pemetaan proses selanjutnya adalah uji normalitas dan homogenitas. Langkah terakhir setelah asumsi normalitas dan homogenitas terpenuhi, dilanjutkan dengan analisis variansi dan uji tukey untuk melihat perbedaan setiap rata-rata jumlah titik panas di setiap kecamatan. 


\section{TITIK PANAS}

Berdasarkan Peraturan Menteri Kehutanan (PERMENHUT) nomor: P.12/Menhut-II/2009 tentang pengendalian kebakaran hutan bahwa titik panas adalah indikator kebakaran hutan yang mendeteksi suatu lokasi memiliki suhu relatif lebih tinggi dibandingkan dengan suhu di sekitarnya dan titik panas diidentikkan dengan adanya titik api, namun dalam kenyataannya tidak semua titik panas mengindikasikan adanya titik api [4].

Tabel 1 Selang Kepercayaan Informasi Titik Panas

\begin{tabular}{ccc}
\hline Level Confidence $(\mathbf{C})$ & Kelas & Keterangan \\
\hline$\leq 30 \%$ & Rendah & Hijau \\
$31 \%-80 \%$ & Sedang & Kuning \\
$\geq 81 \%$ & Tinggi & Merah \\
\hline
\end{tabular}

Sumber: $B M K G, 2018$

Titik panas yang tersebar di tingkat kabupaten, kecamatan, desa serta penggunaan lahan merupakan kejadian yang bisa merugikan bagi makhluk hidup. Titik panas yang tersebar terbagi menjadi beberapa kategori yang dinamakan dengan level confidence, seperti terlihat pada Tabel 1.

\section{ANALISIS VARIANSI}

Uji normalitas adalah sebuah uji yang dilakukan dengan tujuan mengetahui kenormalan data. Salah satu analisis yang dapat digunakan untuk mengetahui normalitas data adalah uji Kolmogorov Smirnov. Uji normalitas data, menggunakan pengujian Kolmogorov Smirnov dengan kriteria jika nilai $P$-Value > taraf sigfikansi maka sebaran data berdistribusi normal. Pedoman pengambilan keputusan menggunakan uji Kolmogorov Smirnov adalah [5]:

a. Nilai $P$-Value $<0,05$ distribusi data adalah tidak normal.

b. Nilai $P$-Value $>0,05$ distribusi data adalah normal.

Selanjutnya, uji homogenitas adalah uji yang menilai adakah perbedaan variansi antara kedua kelompok atau lebih. Menguji homogenitas bisa dengan menggunakan cara yaitu Uji Bartlett, Cohcran, Hae tley, Levene, dan Scheffe [6]. Uji homogenitas menggunakan statistik uji levene dengan mengambil taraf signifikansi 0,05 . Dengan kriteria pengujian yaitu jika nilai $P$-Value $<0,05$ maka varians tidak homogen, sedangkan jika $P$-Value $>0,05$ maka data mempunyai variansi yang sama atau homogen.

Analisis variansi adalah suatu teknik untuk menguji kesamaan beberapa rataan. Analisis variansi tidak hanya digunakan dalam satu faktor perlakuan, tetapi lebih dari beberapa perlakuan. Bila perlakuan hanya terdiri dari satu arah maka disebut klasifikasi eka arah dan apabila terdiri dari dua faktor disebut klasifikasi dwi arah [7]. Pada penelitian ini memiliki subjek setiap perlakuan tidak sama, maka untuk mencari analisis variansi adalah sebagai berikut [8]:

Langkah 1: Menentukan hipotesis $\mathrm{H}_{0}$ dan $\mathrm{H}_{1}$

$\mathrm{H}_{0:} \mu_{1}=\mu_{2}=\mu_{3}=\cdots=\mu_{k}$

$\mathrm{H}_{1:}$ Salah satu $\mu$ tidak sama

Langkah 2: Menentukan daerah penerimaan $\mathrm{H}_{0}$ dan $\mathrm{H}_{1}$

Langkah 3: Menetukan nilai statistik uji

Langkah 4: Kriteria pengujian

$\mathrm{H}_{0}$ diterima jika $\mathrm{F}_{\text {hitung }}<\mathrm{F}_{\text {tabel }}$ atau $P$-Value $>$ taraf signifikansi

$\mathrm{H}_{0}$ ditolak jika $\mathrm{F}_{\text {hitung }}>\mathrm{F}_{\text {tabel }}$ atau $P$-Value $<$ taraf signifikansi

Langkah 5: Kesimpulan

$$
F K=\frac{(Y)^{2}}{\sum_{i=1}^{k} r_{i}}
$$




$$
\begin{aligned}
& J K T=\left(\sum_{i=1}^{k} \sum_{j=1}^{r_{i}} Y_{i j}^{2}\right)-F K \\
& J K P=\left(\sum_{i=1}^{k} \frac{Y_{i}^{2}}{r_{i}}\right)-F K \\
& J K G=J K T-J K P \\
& K T P=\frac{J K P}{d b(P)} \\
& K T G=\frac{J K G}{d b(G)} \\
& \mathrm{db}(\mathrm{P})=\mathrm{k}-1 \\
& \mathrm{db}(\mathrm{G})=\sum_{i=1}^{k}\left(r_{i}-1\right) \\
& \mathrm{db}(\mathrm{T})=\sum_{i=1}^{k} r_{i}-1 \\
& F_{\text {hitung }}=\frac{K T P}{K T G}
\end{aligned}
$$

dengan:

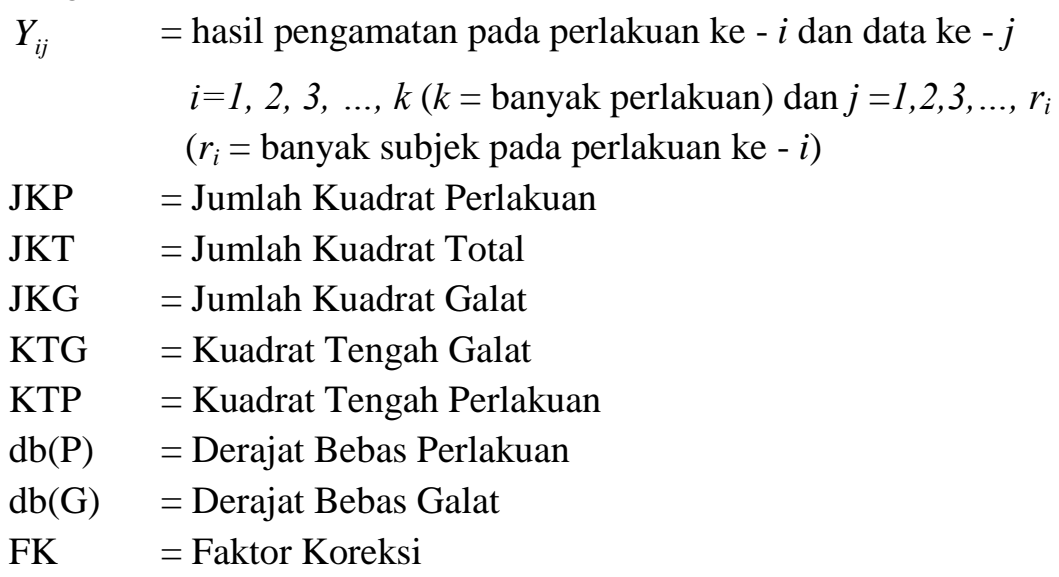

\section{MULTIPLE COMPARISONS}

Analisis variansi merupakan alat uji statistik untuk mengetahui adanya pengaruh, namun belum mampu menunjukkan perlakuan yang berbeda antara satu dengan lainnya, oleh karena itu perlu mengetahui lebih lanjut untuk melihat nilai rata-rata yang tidak sama dengan uji lanjut [8]. Uji lanjut untuk membandingkan antar perlakuan dikenal dengan uji perbandingan berganda. Ada beberapa uji perbandingan berganda yang dapat diketahui yaitu Uji Nyata Terkecil (BNT) atau Least Significance Difference (LSD), Uji Tukey sering disebut Beda Nyata Jujur (BNJ) atau Honest Significance Difference (HSD) dan Uji Jarak Duncan atau Duncan Multiple Range Test (DMRT) [9]. Dalam penelitian ini digunakan Uji Tukey karena banyak perlakuan lebih dari tiga dan perbedaan jumlah sampel pada setiap perlakuan, sehingga uji ini lebih tepat digunakan.

\section{STUDI KASUS}

Pengambilan data dilakukan dari Rupa Bumi Indonesia (RBI) dan National Aeronautics and Space Administration (NASA). Ukuran sampel yang digunakan 877 titik panas pada Bulan Agustus yang tersebar di Kabupaten Kubu Raya. Koordinat yang digunakan adalah $X$ sebagai absis yaitu longitude dalam satuan degree decimal, $Y$ sebagai ordinat yaitu lattitude dalam satuan degree decimal, 
sedangkan confidence adalah cakupan luas titik panas dengan satuan persen (\%). Deskripif confidence titik panas di Kabupaten Kubu Raya, adalah memiliki angka minimum 0\% dan nilai maksimum sebesar $100 \%$. Selanjutnya, sebaran nilai confidence adalah sebesar $23,950 \%$ dengan rata-rata $67,694 \%$.

Titik panas merupakan salah satu indikator kejadian kebakaran hutan dan lahan di suatu wilayah. Berdasarkan data titik panas hasil rekaman satelit NOAA yang dikeluarkan oleh NASA pada Bulan Agustus 2018, dapat diketahui pola sebaran titik panas di wilayah Kabupaten Kubu Raya. Kabupaten Kubu Raya memiliki luas $859.217,8315$ hektar dan tersebar jumlah titik panas sebanyak 877 titik pada 9 kecamatan.

Berdasarkan Gambar 2 dapat dilihat bahwa terjadi dugaan kebakaran, dengan titik panas paling banyak pada level confidence klasifikasi rendah dan sedang banyak terdapat pada Kecamatan Sungai Raya. Kemudian terjadi dugaan kebakaran, sedangkan pada level confidence klasifikai tinggi banyak terdapat di Kecamatan Rasau Jaya. Selanjutnya, berdasarkan jumlah titik panas pada tingkat kecamatan paling sedikit dimiliki oleh Kecamatan Teluk Pakedai. Sedangkan jumlah titik panas paling banyak terdapat pada Kecamatan Sungai Raya. Selanjutnya berdasarkan Gambar 3 dapat diketahui bahwa jumlah titik panas paling banyak pada tingkat desa adalah di Desa Sungai Asam di Kecamatan Sungai Raya.

Pada Gambar 4 dapat diketahui bahwa jumlah titik panas yang tersebar di tingkat penggunaan lahan paling banyak adalah pada area semak. Hal ini terjadi karena aktivitas masyarakat banyak menginterpensi daerah semak untuk dijadikan lahan agar memenuhi kebutuhan manusia dalam penyelenggaraan kehidupannya. Pengelolaan lahan semak yang tidak benar seperti pembukaan lahan dengan cara membakar, dapat tersensor satelit. Daerah kecamatan yang banyak memiliki area penggunaan lahan semak yang memiliki titik panas yaitu pada Kecamatan Rasau Jaya, Kecamatan Sungai Raya dan Kecamatan Kubu.

Pada asumsi normalitas dapat diketahui bahwa data jumlah titik panas pada Gambar 5 (a) tidak terpenuhi karena nilai $P$-Value $(0,010)$ kurang dari taraf signifikansi $(0,05)$. Oleh karena itu dilakukan transformasi Box Cox untuk memenuhi asumsi tersebut. Setelah dilakukan transformasi Box Cox, data terpenuhi asumsi normalitas, dapat dilihat pada Gambar 5 (b) dengan nilai $P$-Value $(0,149)$ lebih besar dari taraf signifikansi $(0,05)$. Kemudian dilakukan Uji homogenitas menggunakan metode Levene dengan hasil $P$-Value $(0,532)$ lebih besar dari taraf signifikansi $(0,05)$, maka dapat disimpulkan setiap kecamatan di Kabupaten Kubu Raya memiliki variansi data yang sama atau homogen.
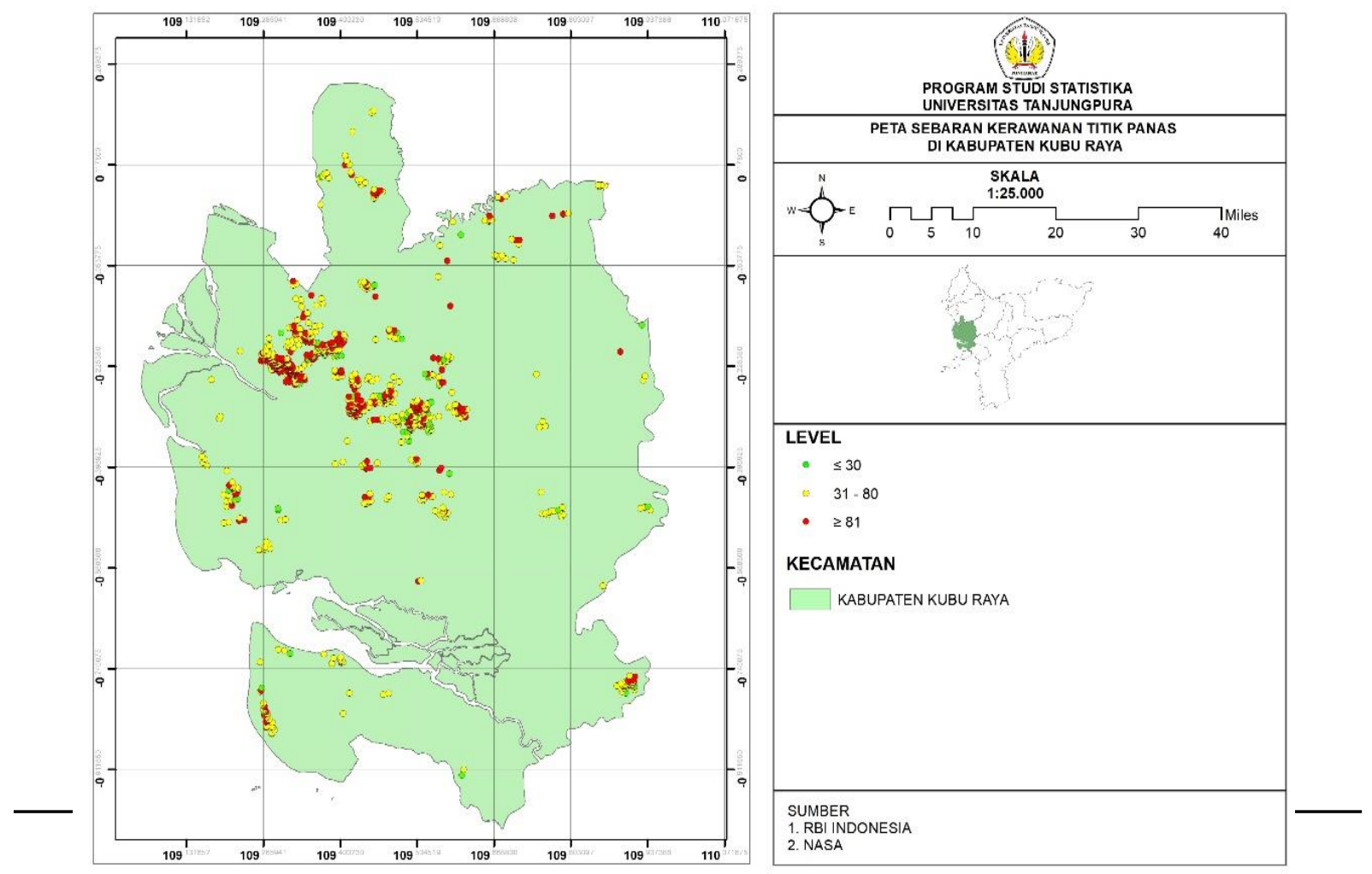


\section{Gambar 1 Sebaran Titik Panas Tingkat Kabupaten}
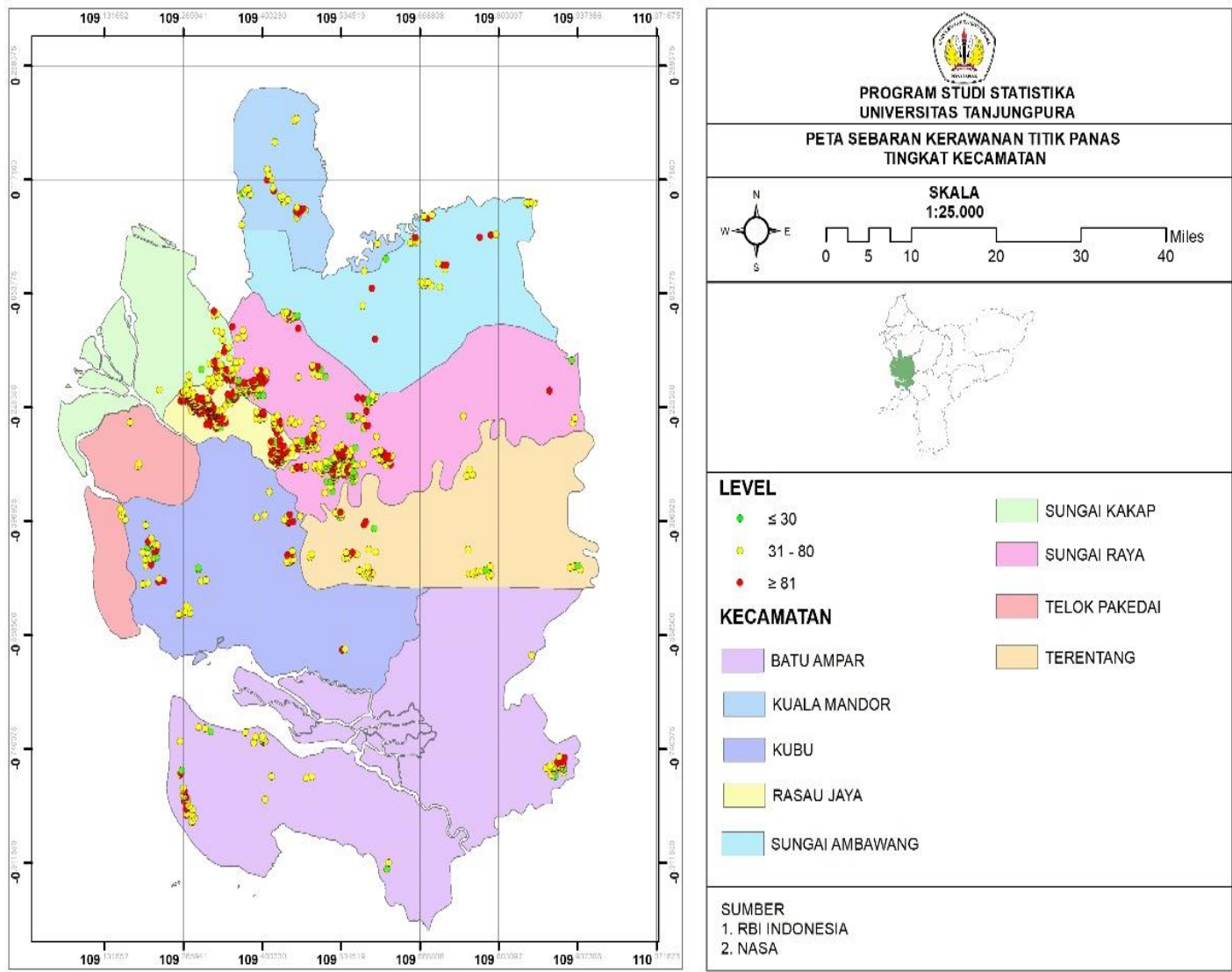

Gambar 2 Sebaran Titik Panas Tingkat Kecamatan

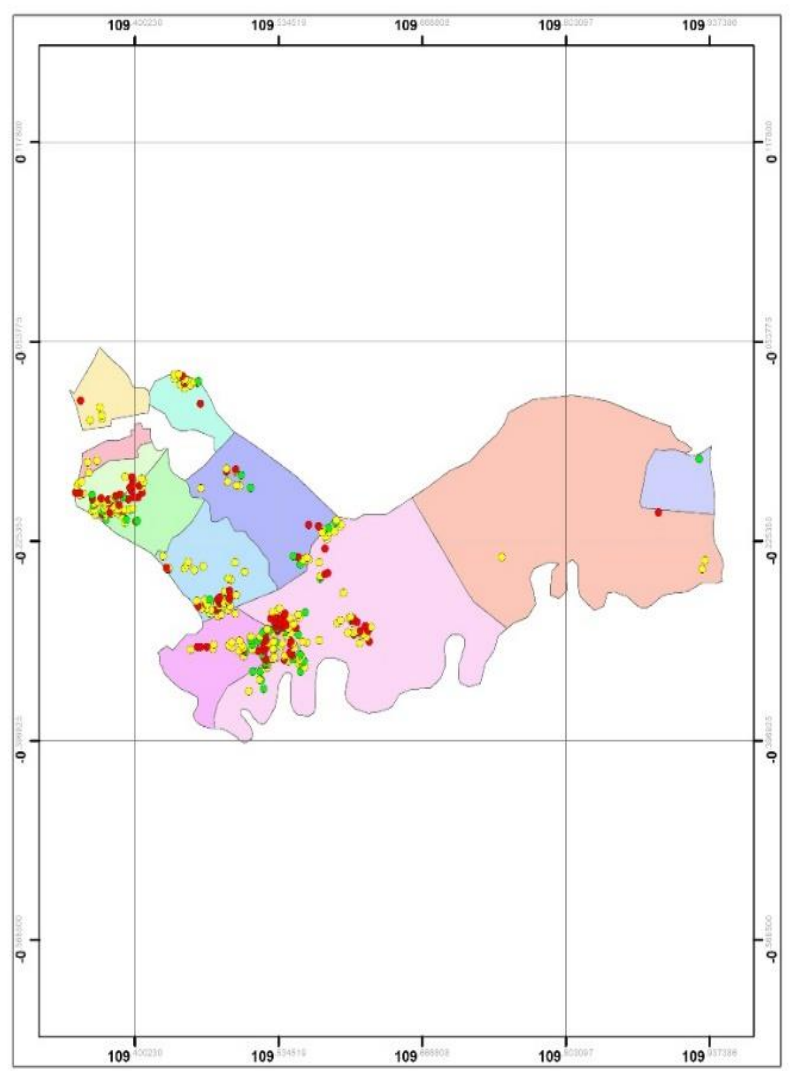

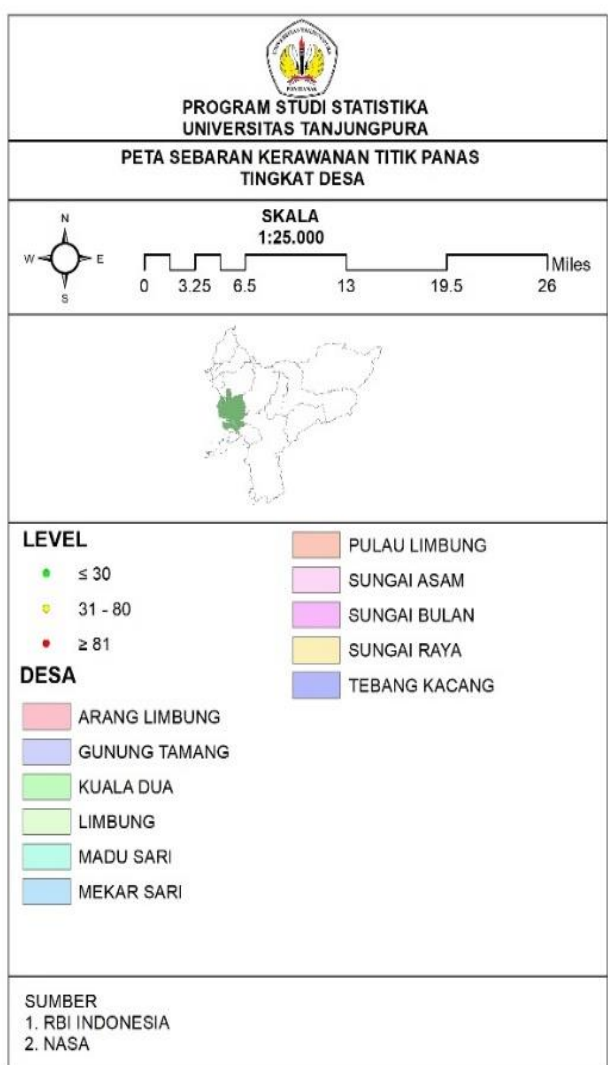


Gambar 3 Sebaran Titik Panas Tingkat Desa di Kecamatan Sungai Raya
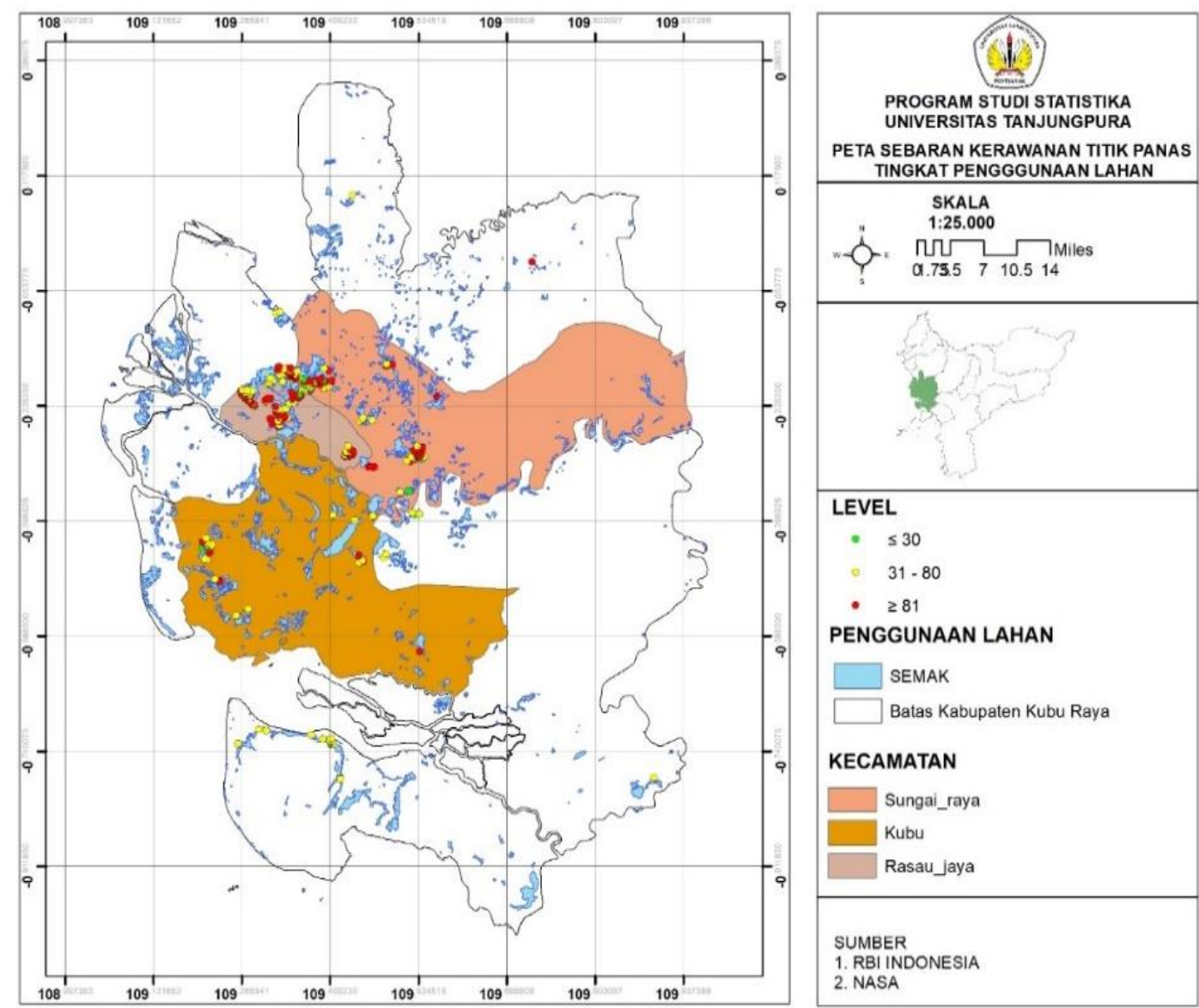

Gambar 4 Sebaran Titik Panas Tingkat Penggunaan Lahan

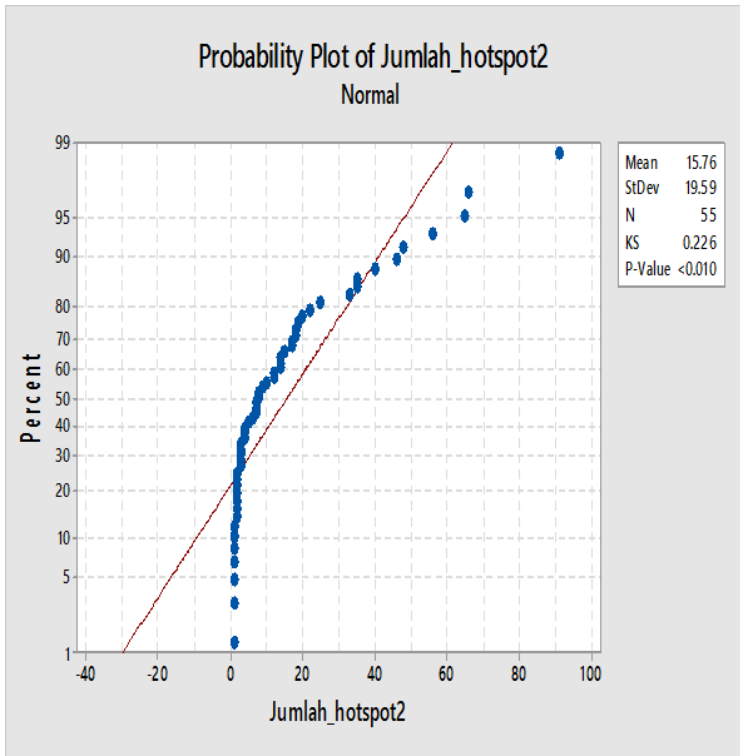

5 (a) Uji Normalitas Pada Data Awal

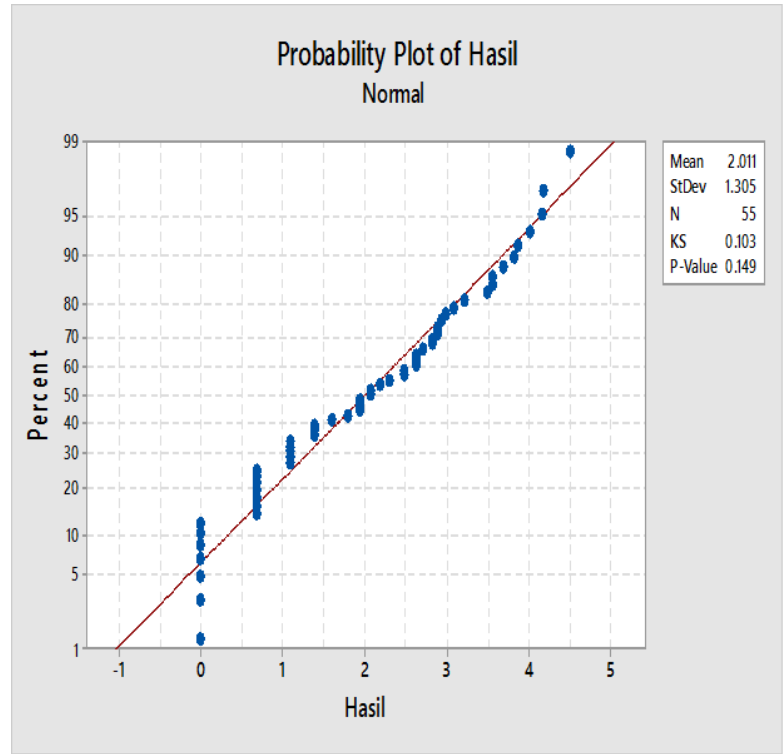

5 (b) Uji Normalitas Hasil Transformasi

Setelah asumsi normalitas dan homogenitas terpenuhi, maka akan dilakukan analisis variansi. Berdasarkan Tabel 2 dapat diketahui bahwa $P$-Value $(0,001)$ lebih kecil dari tingkat signifikansi $(0,05)$ 
sehingga dapat disimpulkan bahwa rata-rata jumlah titik panas di setiap kecamatan berbeda nyata atau memilki perbedaan. Oleh karena itu akan dilanjutkan dengan uji tukey untuk mengetahui perbedaan antara kecamatan. Berdasarkan Tabel 3 pada uji tukey diketahui bahwa perbedaan rata-rata jumlah titik panas pada Kecamatan Rasau Jaya lebih besar dibandingkan dengan Kecamatan Batu Ampar dan Kubu. Sedangkan Kecamatan Teluk Pakedai memiliki rata-rata jumlah titik panas lebih kecil dibandingkan Kecamatan Sungai Raya dan Rasau Jaya.

Tabel 2 Analisis Variansi Jumlah Titik Panas Pada Kecamatan

\begin{tabular}{lccccc}
\hline $\begin{array}{c}\text { Sumber } \\
\text { Variansi }\end{array}$ & $\mathrm{db}$ & $\begin{array}{c}\text { Jumlah } \\
\text { Kuadrat }\end{array}$ & $\begin{array}{c}\text { Rata-rata } \\
\text { Kuadrat }\end{array}$ & $\mathrm{F}_{\text {hitung }}$ & P-Value \\
\hline Perlakuan & 8 & 38,08 & 4,760 & 4,07 & 0,001 \\
Galat & 46 & 53,84 & 1,171 & & \\
Total & 54 & 91,92 & & & \\
\hline
\end{tabular}

Tabel 3 Hasil Uji Tukey Pada Jumlah Titik Panas Setiap Kecamatan P-Value < 0,05

\begin{tabular}{clcc}
\hline No & Kecamatan & $\begin{array}{c}\text { Defference } \\
\text { Of Means }\end{array}$ & $\begin{array}{c}\text { Adjusted } \\
\text { P-Value }\end{array}$ \\
\hline 1 & Rasau Jaya - Batu Ampar & 2,116 & 0.019 \\
2 & Rasau Jaya - Kubu & 2,116 & 0.010 \\
3 & Teluk Pakedai - Sungai Raya & $-2,432$ & 0.030 \\
4 & Teluk Pakedai - Rasau Jaya & $-3,354$ & 0,002 \\
\hline
\end{tabular}

\section{PENUTUP}

Berdasarkan penelitian yang telah dilakukan maka diperoleh kesimpulan sebagai berikut:

1. Jumlah sebaran titik panas di Kabupaten Kubu Raya adalah sebanyak 877 titik, tersebar di 9 kecamatan. Jumlah titik panas paling banyak terdapat pada Kecamatan Sungai Raya untuk tingkat kecamatan, Desa Sungai Asam untuk tingkat desa, dan area semak untuk penggunaan lahan.

2. Analisis variansi menunjukkan bahwa jumlah titik panas pada setiap kecamatan memiliki perbedaan rata-rata. Selanjutnya, Uji tukey dapat diketahui juga bahwa rata-rata jumlah titik panas pada kecamatan Rasau Jaya lebih besar dibandingkan dengan Kecamatan Batu Ampar dan Kecamatan Kubu. Sedangkan Kecamatan Sungai Raya dan Rasau Jaya memiliki rata-rata jumlah titik panas lebih kecil dibandingkan Kecamatan Teluk Pakedai.

\section{DAFTAR PUSTAKA}

[1]. World Wide Fund (WWF) - Indonesia, https://www.wwf.or.id/, [Diakses pada tanggal 23 Januari 2018],2009.

[2]. Ramadhan, M. G.; Putri, A. S.; Kurniawan, A.; dan Irawan. A.S., Prioritas Arah Penetapan Titik Pengamatan Kecepatan Vertikal di Kalimantan Menggunakan Analisis Anisotropi, Jurnal Meteorologi Kliamtologi dan Geofisika, 5(3): 1-9, 2018.

[3]. Adinugroho, W. C.; Suryadiputra, I. N. N.; dan Saharjo, B. H., Panduan pengendalian pengendalian kebakaran hutan dan lahan gambut, Wetlands International, Bogor; 2005.

[4]. Rahadian, T. D. A.; Prasetyo, Y.; dan Haniah., Analisis Sebaran dan Perhitungan Hotspot Menggunakan Citra Satelit NOAA-18/AVHRR dan AQUA Modis berbasis Algoritma Kanal Termal, Jurnal Geodesi Undip, 5(1): 275-284, 2016.

[5]. As'ari, R., Pengetahuan dan Sikap Masyarakat dalam Melestarikan Lingkungan Hubungan dengan Perilaku Menjaga Kelestarian Kawasan Bukit Sepuluh Ribu di Kota Tasikmalaya, Jurnal GeoEcko., 4: 9-18. 2018.

[6]. Setiawan F., Aplikasi Penginderaan Jauh dan GIS untuk Penentuan Lokasi TPA Sampah di Kota Surabaya, Prosiding Seminar Nasional Aplikasi Teknologi Informasi, 2010.

[7]. Simbolon, H., Statistika, Graha Ilmu, Yogyakrta; 2013. 
[8]. Quadratullah, M. F., Statistika Terapan, CV Andi Offset, Yogyakarta; 2014.

[9]. Harsojuwono, B, A.; Arnata, I.W.; dan Puspita, G, A, K, D., Rancangan Percobaan, Lintas Kata, Jakarta; 2011.

SUJIMAN

NAOMI NESSYANA DEBATARAJA :

YUNDARI
: Jurusan Matematika FMIPA UNTAN, Pontianak sujimanjim21@student.untan.ac.id : Jurusan Matematika FMIPA UNTAN, Pontianak naominessyana@math.untan.ac.id

: Jurusan Matematika FMIPA UNTAN, Pontianak yundari@math.untan.ac.id 